\title{
Menikahi Wanita Hamil (Karena Zina dan Perkosaan) Serta Aborsi Anak Hasil Zina Perspektif Hukum Islam
}

\author{
Wahyuningsih \\ Institut Agama Islam Negeri Salatiga \\ wahyuningsihsih99@gmail.com
}

\begin{abstract}
Marriage in the knowledge of fiqih is a shari'at that is stated in Islam to bind a mixture of relationships between a man and a woman who is not a mahrom, so that both have rights and obligations. The phenomenon that often occurs at this time is the rampant promiscuity which results in many pregnant women outside of marriage. The thing that creates a dilemma is that almost all actors are Muslim, be they students, college students, even adults. An incident that violates Islamic law has its own legal area to discuss. In fiqh, adultery is called fahsya because adultery causes further evils. The ugliness of this phenomenon has a negative impact on women, their families, and the most sad thing is the negative impact on the child that is being conceived when it is born, indicating an evil that seems to never run out. In this study, the authors used a library approach (library reseach). The views of scholars regarding the law of marrying a pregnant woman because of adultery are in various views that refer to the Al-Quran, Hadith.
\end{abstract}

Keywords: Marriage, Pregnant Woman, Adultery, Abortion

\begin{abstract}
Abstrak
Pernikahan dalam khazanah ilmu fiqih merupakan syari'at yang disyari'atkan dalam islam untuk mengikat percampuran hubungan antara laki-laki dan perempuan yang bukan mahrom, sehingga keduannya memiliki hak dan kewajiban. Fenomena yang banyak terjadi pada zaman ini adalah maraknya pergaulan bebas yang berakibat pada banyaknya perempuan hamil diluar pernikahan. Hal yang membuat dilemma yaitu hampir semua pelaku yang beragama islam, baik itu pelajar, mahasiswa, bahkan dewasa. Suatu kejadian yang melanggar hukum islam, memiliki ranah hukun tersendiri untuk dibahas. Dalam fiqih, zina disebut dengan fahsya karena zina menimbulkan keburukan-keburukan selanjutnya. Keburukan dari fenomena tersebut memiliki dampak yang negative bagi perempan, keluarganya, dan yang paling miris adalah dampak negatif bagi anak yang sedang dikandungnya apabila telah lahir, menandakan keburukan yang seakan tidak pernah habis. Dalam penelitian ini, penulis menggunakan pendekatan pustaka (library reseach). Pandangan ulama mengenai hukum menikahi wanita hamil karena zina dalam berbagai pandangan yang mengacu pada Al Qur'an, Hadits.
\end{abstract}

Kata Kunci: Pernikahan, Wanita Hamil, Zina, Aborsi 


\section{A. PENDAHULUAN}

Pernikahan dalam islam memiliki fungsi sebagai proses regenerasi dan keberlangsungan hidup. Manusia memiliki hak untuk menyalurkan nafsunya sebagai makhluk ciptaan Allah SWT. Sebagai agama rahmatan lil 'alamin, islam telah mengatur semua sisi kehidupan. Untuk menghindari adanya perbuatan yang dilarang agama, seperti perzinahan, pergaulan bebas masa kini dan protistusi, pernikahan hadir sebagai solusi penyaluran nafsu yang bahkan mengandung pahala didalamnya. Karena setelah ijab kabul diucapkan, maka perbuatan yang dilarang antara laki-laki dan perempuan dihalalkan dengan ketentuan tertentu. Islam memberikan solusi dan anjuran untuk menikah memiliki beberapa motivasi jelas dan memberikan dampak positif yang lebih besar kepada perempuan, keluarga dan masyarakat luas. Itu karena pernikahan adalah salah satu tanda kebesaran Allah SWT yang diberikan kepada umat manusia. Dengan adanya pernikahan manusia dapat mempertahankan keberlangsungan hidup dengan turun temurun dan melestarikan agama islam di bumi.

Selain tujuan pernikahan untuk melestarikan keturunan, tujuan pernikahan lain yang tidak kalah penting adalah ibadah yang lebih dapat dilakukan setelah melai pernikahan dan dapat mengangkat derajat hubungan laki-laki dan perempuan menjadi terhormat serta dapat menghadirkan ridho Allah SWT untuk menjadikan keluarga yang sakinah, mawaddah, wa rahmah. Dengan adanya pernikahan dapat menghalalkan pergaulan dan membatasi hubungan dengan orang yang bukan mahramnya. Kenyataan yang terjadi dewasa ini, terjadi penyimpangan seksual di kalangan muda-mudi.

Kehamilan di luar pernikahan disebabkan karena pasangan muda-mudi sering memanfaatkan kesempatan dan perkembangan teknologi yang menjerumuskan mereka kepada pergaulan yang menyimpang dari aturan, norma, dan agama. ${ }^{1}$ Untuk menyelesaikan permasalahan kehamilan diluar nikah akibat perzinahan, orang tua akan menikahkan anaknya dengan laki-laki yang menghamilinya atau dengan laki-laki lain yang tidak menghamilinya. Hal itu sudah menjadi pilihan orang tua kepada anak perempuannya. Kemudian mereka akan menikahkan anak perempuannya lagi setelah perempuan melahirkan. Praktik seperti ini, berlandaskan apa yang mereka pahami tentang ketentuan nikah hamil dalam fikih klasik.

\footnotetext{
${ }^{1}$ Asep Saepudin Jahar, Euis Nurlaelawati, Jaenal Aripin, Hukum Keluarga, Pidana, Dan Bisnis: Kajian Perundang-undangan Indonesia, Fikih, Dan Hukum Internasional, (Jakarta: Kencana, 2013), hlm. 50
} 
Menyelesaikan masalah kehamilan hasil perzinahan merupakan jalan baik untuk menjaga diri perempuan agar tidak semakin menambah dosa yang diperbuatnya. Segelintir orang, menyelesaikan masalah kehamilan di luar nikah dengan jalan aborsi. Dalam madzhab Hambali, menegaskan bahwa melakukan aborsi adalah dosa, karena adanya pendarahan yang menyebabkan miskram yang menjadi petunjuk bahwa hal tersebut diharamkan. Aborsi menjadi isu kontroversional karena tidak hanya menyangkut pada dunia kesehatan, akan tetapi juga menyangkut etika moral, hukum dan agama. ${ }^{2}$

Dari paparan latar belakang di atas, maka peneliti tertarik mengetahui, menganalisis, dan memahami bagimana hukum islam memandang dan menyikapi pernikahan wanita hamil serta bagaimana status anak yang dikandungnya apabila telah lahir, dan bagaimana hukum aborsi menurut fuqaha.

Dengan adanya pergeseran nilai sosial, agama, dan budaya, menyebabkan perubahan moralitas yang terjadi di masyarakat tentang adanya perzinahan benar adanya terjadi. Banyaknya kasus perempuan hamil diluar nikah, menyebabkan para orang tua memilih menikahkan anaknnya untuk menjaga kehormatan keluarganya. ${ }^{3}$

Dalam hal inilah yang menarik peneliti untuk meneliti kejadian yang kerap melanda kalangan muda-mudi dengan pendekatan fiqih (hukum islam) yang berlaku, baik secara syar'I ataupun dalam hukum islam yang terjadi di Indonesia.

\section{B. PEMBAHASAN}

\section{Hukum Menikahi Wanita Hamil (Karena Zina dan Perkosaan)}

Islam sebagai yang bersifat rahmatan lil 'alamin telah berusaha untuk melindungi masyarakat muslim dari penyimpangan sosial yang membinasakan, yaitu adalah seks bebas atau dalam islam disebut dengan zina. Zina adalah hubungan antara laki-laki dan perempuan di luar pernikahan. Islam telah melarang dan mengharamkan zina, hal ini dapat kita temukan pada Al Qur'an surat Al Isra' ayat 32:

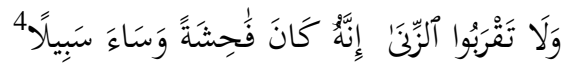

${ }^{2}$ Dewani Romli, "Aborsi Dalam Perspektif Hukum Positif Dan Hukum Islam (Suatu Kajian Komparatif)”, Jurnal Al Al 'Adalah, Vol. X, No. 2, 2011

3 Salamah Eka Susanti. (2018). Perubahan Sosial, Ijtihad dan Dinamika Hukum Islam. AsySyari'ah: Jurnal Hukum Islam , 4 (1), 63

${ }^{4}$ https://tafsirweb.com/4636-quran-surat-al-isra-ayat-32.html, diakses pada tanggal 6 Desember 2020 pada jam 18.16 WIB 
"Dan janganlah kamu mendekati zina; sesungguhnya zina itu adalah suatu perbuatan yang keji dan suatu jalan yang buruk"

Dalam islam, zina terbagi menjadi dua yaitu berdasarkan hukuman yang akan dijalankan. Pertama, zina muhsan, yaitu adalah zina yang dilakukan oleh laki-laki dan perempuan yang sudah baigh, berakal, merdeka, dan pernah menikah, baik itu sudah bercerai ataupun masih terikat suatu pernikahan. Hukuman keduannya adalah rajam. Kedua, zina ghairu muhsan, yaitu adalah zina yang dilakukan oleh laki-laki dan perempuan yang tidak memiliki ikatan pernikahan. Hukuman yang disyariatkan adalan cambuk 100 kali dan diancam diasingkan.

Istilah " menikahi wanita hamil (diluar nikah karena zina atau pekosaan)” yaitu akad nikah yang dilakukan oleh perempuan pada saat ia sedang dalam keadaan hamil disebabkan terjadinya hubungan terlarang yang mempertemukan dua kemaluan (hubungan kelamin) antara dirinya dengan laki-laki, dengan hubungan diluar nikah, bisa karena zina atau perkosaan. ${ }^{5}$

Para ulama berbeda pendapat tentang menikah dengan wanita hamil. Dalam hal ini sepertinyang sudah disebutkkan diatas, ada dua kasus yang dapat diambil dari kasus ini. Pertama, nikahnya wanita hamil karena zina dengan laki-laki yang menzinainya. Kedua, nikahnya wanita hamil karena zina dengan laki-laki yang tidak mengzinainya. Dalam hal ini, para imam empat madzhab berbeda pendapat tentang siapa yang boleh menikahi wanita hamil karena zina, apakah itu yang menghamilinya, ataukah laki-laki lain ? Imam Hanafi berpendapat ketika laki-laki yang menghamilinya menikahinya adalah boleh, boleh dalam arti ketika sudah menikah maka boleh langsung menggaulinya. Apabila yang menikahi wanita tersebut adalah orang yang tidak menghamilinya, hukumya boleh dengan syarat tidak menggaulinya hingga ia melahirkan. Kemudian Imam Syafi'I berpendapat bahwa laki-laki baik yang menghamilinya ataupun tidak, boleh menikahinya. Berbeda dengan Imam Maliki dan Imam Hanbali yang berpendapat bahwa laki-laki yang tidak menghamilinya, tidak

${ }^{5}$ Saiful Millah, Pernikahan Wanita Yang Hamil Di Luar Nikah Dan Akibat Hukumnya : Telaah Atas Dualisme Fikih Dan Kompilasi Hukum Islam, Misykat, Volume 02,Nomor02, Desember2017 
boleh menikahinya kecuali telah habis masa iddahnya. Akan tetapi dalam hal ini, Imam Hambali memberikan syarat satu lagi yaitu wanita harus bertaubat. ${ }^{6}$

Menurut Sayid Sabiq ${ }^{7}$ menikahi seorang pezina tidak diperkenankan kecuali telah bertaubat, hal ini mengikuti pendapat Imam Hanbali dengan dalil Qur'an Surat An Nur ayat 3

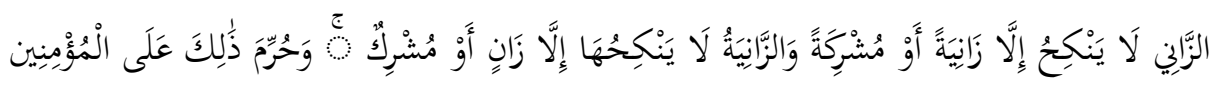

"Laki-laki yang berzina tidak mengawini melainkan perempuan yang berzina, atau perempuan yang musyrik; dan perempuan yang berzina tidak dikawini melainkan oleh laki-laki yang berzina atau laki-laki musyrik, dan yang demikian itu diharamkan atas orang-orang yang mukmin"»8

Ayat diatas menjelaskan bahwa orang mukmin dilarang menikahi pezina dan musyrik karena mereka tidak layak untuk dinikahi, kecuali yang menikahi pezina atau musyrik pula. Dari ayat diatas, para fuqaha berbeda pendapat tentangnya. Kelompok pertama melihat ayat tersebut secara dhahir saja, maka laki-laki yang bukan pezina ketika menikahi wanita pezina adalah haram. Sedangkan kelompok kedua memahami ayat ini sebagai ancaman bukan pengharaman.

Madzhab Hanafi berpendapat jika perempuan yang melakukan zina tidak hamil, maka akad laki-laki yang tidak berzina dengan perempuan itu adalah sah. Setidaknya ada dua alasan menurut Wahbah $\mathrm{Az}$ zuhaili ${ }^{9}$ bolehnya laki-laki yang tidak berzina menikahi perempuan pezina dengan syarat tidak menggaulinya sampai dia melahirkan dan perempuan tidak hamil. Pertama, perempuan yang pernah berzina tidak disebutkan dalam perempuan yang haram dinikahi dengan Dalil Qur'an Surat An Nisa ayat 24. Kedua, tidak ada kehormatan bagi air sperma zina. Karena zina tidak menetapkan nasab dengan dalil hadits Rasulullah SAW “ anak bagi yang membuat hamil ibunya dan anak yang lahir dari pelacur, tidak dapat dinasabkan kepada pelaku yang menghamilinya” diwirayatkan oleh Jamaah kecuali Abu Dawud dari Abu hurairah.

Imam Maliki mengharamkan menikahi perempuan pezina dalam keadaan hamil kecuali dia sudah terbebas dari masa iddahnya, yaitu adalah melahirkan. Imam Maliki

\footnotetext{
${ }^{6}$ Gus Arifin, Menikah Untuk Bahagia; Fiqih Tentang Pernikahan dan Kamasutra Isl ami, (Jakarta: PT. Elex Media Komputindo, 2020), hlm. 273

${ }^{7}$ Sayyid Sabiq, Fiqih Sunnah, Penerjemah Ahmad Dzulfikar dan Muhamad Khoiyrurrijal, (Depok: Keira Publishing, 2015, Jilid 4), hlm. 247

${ }^{8}$ https://tafsirq.com/24-an-nur/ayat-3

${ }_{9}^{9}$ Wahbah Az Zuhaili, Fiqih Islam Wa Adillatuhu, jiid 9, penerjemah; Abdul Hayyi Al Kattani, dkk, (Depok: Gema Insani, 2016), hlm. 144-145
} 
megemukakan dalil Nabi SAW riwayat Abu Dawud " tidak halal bagi seseorang yang beriman kepada Allah SWT dan hari akhir menyiramkan airnya kepada tanaman lain" hal itu dikarenakan kekhawatiran akan tercampurnya nasab anak yang ada dalam kandungan. Apabila akad nikah tetap dijalankan maka akadnya adalah fasid (rusak) dan wajib dibatalkan.

Madzhab Hambali, menyandarkan hukum menikahi wanita hamil dalam tujuh pembahasan: ${ }^{10}$

a. Hadits dari riwayat Abu Dawud " tidak halal bagi seseorang yang beriman kepada Allah SWT dan hari akhir menyiramkan airnya kepada tanaman lain".

b. Hadits Abu Sa'id Al Khudry dari Nabi SAW berbicara mengenai tawanan perang Authas " Tawanan wanita yang hamil tidak boleh disetubuhi, hingga ia melahirkan, dan tawanan wanita yang tidak hamil disetubuhi hingga ia haid sekali”.

c. Hadits Abu Dar'da dari Nabi SAW bahwa Beliau membawa wanita hamil ke depan tenda dan berkata " Barangkali dia ingin menyetubuhinya?" dan Berkata "Ya", Kemudian Nabi Bersabda "Sungguh aku telah berkeinginan untuk melaknatnya dengan laknat yang dibawanya masuk kedalam kubur. Bagaimana dia mewarisinya sedangkan dia tidak halal baginya? Bagaimana dia menggunakannya sedangkan dia tidak halal baginya?"

d. Dalam hadits ini, Nabi Muhammad mengancam barang siapa yang menikahi wanita yang sedang hamil. Maka dari itu menikahi wanita hamil tidak boleh.

e. Mengqiyaskan kepada wanita hamil lainnya yang disepakati haram dinikahi, dengan illat adanya kandungan dalam dirinya.

f. Pada intinya, 'iddah yang disyariatkan untuk mengetahui kebebasan rahim. Sebelum beriddah, bisa saja wanita yang berzina itu hamil. Maka akad pernikahannya batil atau tidak sah.

g. Terjadinya percampuran nasab apabila wanita yang berzina tidak hamil karena bisa saja hamil dengan laki-laki pertama.

a. Mengqiyaskan persetubusan syubhat dengan illat bahwa itu persetubuhan kemaluan.

Dalam KHI yang berlaku di Indonesia, menikahi wanita hamil terdapat dalam pasal 53 dan meliputi tiga pembahasan, yaitu: ${ }^{11}$

${ }^{10}$ Yahya Abdurrahman Al Khatib, Fikih Wanita Hamil, penerjemah; Mujahidin Muhayan, (Jakarta: Qishti Press, 2005), hlm. 95-97 
a. Seorang wanita hamil diluar nikah, dapat dinikahkan dengan laki-laki yang menghamilinya.

b. Pernikahan wanita hamil seperti yang disebut pada ayat (1) dapat dilangsungkan tanpa menunggu lebih dahulu kelahiran anaknya.

c. Dengan dilangsungkannya pernikahan pada saat wanita hamil, tidak diperlukan pernikahan ulang setelah anak yang dikandung lahir.

Kompilasi Hukum Islam yang berlaku di Indonesia, tampaknya hanya mengatur menikahi wanita hamil diluar nikah dan tidak mengatur perbuatan zina kepada orang yang sudah mempunyai suami atau istri. Dalam KHI tentang pernikahan wanita yang hamil karena zina boleh dinikahkan dengan yang menzinainya sesuai dengan QS. An Nur ayat.

\section{Kedudukan dan Akibat Hukum Anak Di Luar Nikah}

Menurut Muhtarom ${ }^{12}$ sebagaimana mengutip Sayid Sabiq dalam bukunya Fiqih Sunnah, ada beberapa akibat dari anak hasil zina sebagai hukuman agar manusia tidak terjerumus kedalam zina.

a. Zina dapat menghilangkan nasab dengan demikian tidak akan mendapat jatah warisan.

b. Zina dapat menjadikan penularan penyakit yang berbahaya kepada yang melakukannya dan anaknya.

c. Zina merupakan salah satu akibat terjadi pembunuhan, karena rasa cemburu yang merupakan tabiat manusia.

d. Zina dapat menghancurkan keutuhan pernikahan dan meruntuhkan eksistensinya.

e. Zina hanya sekedar hubungan yang sementara, tidak ada masa depan dan kelanjutannya.

Dalam kajian kitab fikih, tidak ada yang menyebutkan anak di luar nikah. Akan tetapi menyebutkan dengan anak zina. Menurut islam, anak zina secara hukum tidak memiliki hubungan dengan nasab kepada ayahnya, tetapi hanya memilliki nasab dengan ibunya. Dengan demikian tanggung jawab materi, spiritual dan segala yang

\footnotetext{
${ }^{11}$ Seri Pustaka Yustisia, Kompilasi Hukum Islam, (Yogyakarta: Pustaka Widyatama, 2006), hlm. 29

12 Ali Mohtarom, Kedudukan Anak Hasil Hubungan Zina Menurut Hukum Islam Dan Hukum Positif, Jurnal al-Murabbi, Volume 3 Nomor 1, Juni 2018
} 
diperlukannya jatuh kepada ibunya dan keluarga ibunya demikian pula dalam hak waris mewaris. $^{13}$

Pendapat imam empat madzhab tentang anak zina sebagai peringatan bahwa perbuatan zina tidak dibenarkan serta sebagai efek jera dari perbuatan zina. Imam Malik dan Imam Syafi'I dikarenakan anak zina tidak terkait nasab dengan bapaknya, maka, laki-laki (bapak) boleh menikahi anak perempuannya, cucu perempuannya, saudara perempuan dan keponakan dari hasil zina. Dikarenakan perempuan-perempuan tersebut tidak memiliki kaitan nasab syar'I dengannya. Hal ini merupakan jalan keluar dari kesulitan menuju kepada kesulitan yang lebih besar. Sedangkan pendapat Imam Hanafi dan Imam Hanbali, melarang bapaknya untuk menikahi anaknya dan perempuan yang disebut di atas dengan argument bahwa anak adalah anak menurut tradisi akan tetapi diwaktu yang bersamaan tidak mendapat waris. ${ }^{14}$

Dalam pandangan fiqih, anak hasil zina (diluar pernikahan yang sah) menempati dua keadaan. ${ }^{15}$ Pertama, anak yang dihamili diluar pernikahan yang sah, akan tetapi lahir dalam pernikahan yang sah. Menurut madzhab Maliki dan Syafi'I, anak yang lahir setelah enam bulan dari ibu dan bapaknya, maka anak tersebut dinasabkan kepada bapaknya. Jika anak trsebut dilahirkan sebelum usia enam bulan, maka anak tersebut dinasabkan kepada ibunya. Sedangkan pendapat madzhab Hanafi dan Hanbali anak yang lahir diluar nikah tetap dinasabkan kepada bapaknya sebagai anak yang sah. Kedua, anak yang dihamili dan dilahirkan diluar pernikahan yang sah. Anak dalam status ini memiliki akibat hukum:

a. Tidak memiliki hubungan nasab dengan bapaknya akan tetapi hanya memiliki nasab dengan ibunya.

b. Bapak tidak wajib memberi nafkah, akan tetapi dia merupakan anak biologisnya.

c. Tidak saling mewarisi harta bapaknya, dikarenakan hubungan nasab merupakan penyebab mendapat warisan.

d. Bapak tidak dapat menjadi wali nikah dari anak perempuan.

13 Kudrat Abdillah dan Maylissabet, Sejarah Sosial Status Dan Hak Anak Di Luar Nikah, (Pamekasan: Duta Media Publishing, 2010), hlm. 18

${ }^{14}$ Muhammad Jawad Mughniyah, Fiqih Lima Madzhab, Penerjemah; Masykur A.B, dkk, (Jakarta: PT.Lentera Basritama, 2004), hlm. 395-397

${ }^{15}$ Hamid Pongoliu, Kedudukan Anak Lahir Di Luar Nikah Dalam Perspektif Hukum Islam Dan Hukum Positif, Jurnal Al-Mizan Vol. 9 No. 1 Juni 2013 
Dalam perundang-undangan yang berlaku di Indonesia, anak yang lahir diluar nikah: ${ }^{16}$

a. UU No. 1 Tahun 1974 pasal 43 ayat 1, menyatakan anak yang dilahirkan di luar pernikahan, hanya mempunyai hubungan perdata dengan ibunya dan keluarga ibunya. Dalam hasil uji coba materi menjadi anak yang dilahirkan diluar pernikahan mempunyai hubungan perdata dengan kedua orang tua biologisnya dan keluarganya dapat mengajukan tuntutan ke pengadilan untuk dapat memperoleh pengakuan dari bapak biologisnya.

b. Kompilasi Hukum Islam (KHI) pasal 100, menyebutkan anak yang lahir diluar perkawinan hanya mempunyai hubungan nasab dengan ibunya dan keluarga ibunya.

Dengan demikian, apabila anak lahir kurang dari enam bulan sejak perkawinan, maka anak tersebut tidak dapat dihubungkan nasabnya kepada bapaknya, baik itu lahir dalam pernikahan yang sah sekalipun. Ia hanya memiliki hubungan nasab dengan ibunya dan keluarganya saja, ini yang membedakan antara hukum islam (fiqih) dengan hukum pernikahan di Indonesia.

\section{Aborsi: Antara Dosa Dan Solusi}

\section{Pengertian Aborsi}

Dalam dunia kedokteran dikenal dengan nama abortus yang berarti berakhirnya suatu kehamilan sebelum usia kandungan 22 mimggu. ${ }^{17}$ Aborsi dapat disebut dengan menggugurkan kandungan dengan cara mengeluarkan janin dari rahim sebelum janin dapat hidup diluar kandungan. Dengan kata lain, janin belum memiliki tanda-tanda kehidupan pada manusia, seperti mendengar, aktivitas otak, dan sirkulasi darah.

Aborsi dapat terjadi secara alami (spontan) ataupun buatan. Aborsi spontan terjadi begitu saja disebabkan keadaan yang tidak normal. Sedangkan aborsi buatan terdapat dua bagian, yaitu; pertama, bersifat illegal (abortus provocatus criminal), kedua, bersifat legal (abortus provocatus therapeuticus). ${ }^{18}$

\footnotetext{
${ }^{16}$ Micky Giovanni Montol, Tinjauan Yuridis Anak Hasil Zina Dilihat Dari Ketentuan Hukum Islam, Jurnal Lex Crimen, Vol. 4, No. 5, Juli 2017

${ }^{17}$ Sudarto, Masail Fiqhiyah Al Haditsah, (Yogyakarta: DEEPUBLISH, 2020), hlm. 72-73

18 Tanti Kirana Utami \& Aji Mulyana, Tanggung Jawab Dokter Dalam Melakukan Aborsi Tanpa Seijin Ibu Yang Mengandung Ata u Keluarga Dalam Perspektif Hukum Positif Di Indonesia, Jurnal Mimbar Justitia, Vol. 1. No. 02, 2015
} 
Dalam islam janin yang berusia 16 minggu dapat disamakan dengan manusia dikarenakan peredaran darah sudah berfungsi dengan semestinya. Dalam hal ini Nabi Muhammad SAW telah memberikan petunjuk dalam sebuah hadits. ${ }^{19 ،}$ diriwayatkan dari Zaid Bin Wahab dari Abdillah meriwayatkan: Rasulullah SAW, menjelaskan kepada kami, bahwa sesungguhnya seseorang diantara kalian dikumpulkan kejadiannya didalam perut ibunya selama 40 hari sebagai nutfah, kemudian menjadi 'alaqah (segumpal darah), kemudian menjadi mudghah (segumpal daging), dengan masa yang sama, kemudian diutuskan malaikat untuk meniupkan ruh kepadanya".(HR. Muslim).

Aborsi tidak dapat dipandang sederhana karena dari sudut pandang agama adalah dilarang atau haram. Dari sudut pandanng moral diannggap sebagai tindakan asusila yang melanggar HAM. Sedangkan dari sudut pandang kesehatan, aborsi dapat menekan angka kematian ibu yang masih tinggi. ${ }^{20}$ Dalam hal tersebut terjadi apabila harus memilih salah satu untuk diselamatkan dan perlu disetujui dari pihak keluarga maupun ibu yang sedang mengandung.

\section{Jenis Aborsi Dalam Pandangan Fiqih}

Menurut Wijayati seperti yang dikutip dari Masjfuk Zuhdi, ${ }^{21}$ dalam beberapa literatur fiqih, aborsi dapat diklasifikasikan menjadi lima kategori, yaitu; pertama, Aborsi Spontan (Isyqath Az Zati), aborsi yang terjadi tanpa ada sebab dan musabab, artinya terjadi secara alamiah tanpa ada pengaruh luar dan dalam. Kedua, aborsi karena keadaan darurat atau dalam pengobatan (Isqath ad Darury) yang terjadi disebabkan janin yang didalam kandungan membahayakan nyawa dari ibu dan hal ini mengharuskan untuk mengaborsi janin dalam kandungannya. Ketiga, aborsi karena kesalahan (Isyqath al Khatai) tidak berniat melakukan aborsi tapi karena terjadinya kesalahan mengakibatkan kandungannya gugur. Keempat, aborsi mirip sengaja (Isqath sibh al' Amdi). Kelima, aborsi sengaja atau terencana (Isqath al' Amdi), aborsi dengan niat untuk menggugurkan kandungan dengan cara mengonsumsi obat-obatan atau memasukan sesuatu yang akan dapat mengggugurkan kandungannya.

\footnotetext{
${ }^{19}$ Sudarto, ... hlm. 73

${ }^{20}$ Istibsjaroh, Aborsi dan Hak-Hak Reproduksi Dalam Islam, (Yogyakarta: LKiS Yogyakarta, 2012), hlm. 3

${ }^{21}$ Mufliha Wijayati, Aborsi Akibat Kehamilan Yang Tak Diinginkan (KTD): Kontestasi Antara Pro-Live Dan Pro-Choice, Jurnal Studi Keislaman, Volume 15, Nomor 1, Juni 2015
} 


\section{Hukum Aborsi dalam Islam}

Islam sebagai agama yang fitrah dibawa oleh nabi Muhammad SAW sebagai rahmatan lil 'alamin memiliki perlindungan kepada umat manusia yang diantaranya adalah perlindungan jiwa dari ancaman. Hal itu pula yang ditetapkan Allah SWT kepada pelaku aborsi. Aborsi dalam penelitian ini yaitu aborsi anak dalam pernikahan tidak sah (karena zina dan perkosaan) menurut hukum islam agar memeudahkan cakupan bahasan.

Setidaknya faktor dalam melakukan aborsi adalah kelahiran yang tidak diinginkan atau kehamilan yang tidak dikehendaki. Ada beberapa faktor yang melatarbelakangi terjadinya aborsi: ${ }^{22}$

a. Hasil hubungan di luar nikah (Zina) termasuk perkosaan.

b. Faktor kesehatan, karena penyakit tertentunyang membahayakan nyawa ibu.

c. Faktor kecantikan, meyakini bahwa setelah melahirkan dapat mempengaruhi kecantikan dan bentuk tubuh seseorang.

d. Faktor ekonomi, ibu tidak sanggup menanggung biaya hidup bayi dan sebagainya.

Dalam Al Qur'an maupun hadits yang menjadi pedoman dalam sumber hukum islam, terdapat beberapa dalil yang mengacu pada Aborsi. Dalam Al Qur'an dijelaskan melalui surat Al Isra ayat 31 dan 33. Dijelaskan bahwa larangan membuuh anak-anak karena takut dengan kemiskinan dan janganlah membunuh jiwa yang diharamkan dengan haq. Dan ketika membunuh secara dzalim, maka hukum jinayah qishash berlaku dengan ketentuan walinya.

Para ulama berbeda pendapat tentang hukum aborsi, sebagian membolehkan dan sebagian mengharamkannya. Beberapa pendapat tentang hukum aborsi menurut ulama.

a. Haram Mutlak, sejak bertemunya sel telur dan sperma, sudah ada kehidupan dalam kandungan yang sedang mengalami pertumbuhan sebagai persiapan makhluk baru yang bernyawa daka dari itu kita harus menjaganya. ${ }^{23}$ Pendapat ini anut oleh imam Abu Hamid al-Ghazali dari mazhab Syafl'i, Ibnu al-Jauzi dari mazhab Hambali, Ibnu -Hammam dari mazhab Hanafi dan al Dusuqi dari mazhab Maliki.

b. Dibolehkan apabila memiliki udzur, sebelum usia janin 120 hari, janin belum bernyawa dan belmu ditiupkan ruh padanya. Janin hanya dipandang bernyawa

22 Astutik, Aborsi Akibat Perkosaan Dalam Perspektif Hukum Kesehatan, (Sidoarjo: Zifatama Jawara, 2020), hlm. 107

${ }^{23}$ Tina Asmarawati, Hukum dan Abortus, (Yogyakarta: DEEPUBLISH, 2013), hlm. 29 
ketika perkembangannya lebih dari 120 hari, itulah yang disyariaykan hadits nabi, akan tetapi memiliki udzur yang jelas. Pendpat ini dianut oleh madzhab Hanafi. ${ }^{24}$

c. Makruh, yaitu aborsi sejak pembuahan atau belum ditiupkan roh. Pendapat ini di anut oleh madzhab Syafi'I seperti imam Ramli dan madzhab Maliki.

Hukum asli aborsi adalah dosa atau haram. Barang siapa yang melakukan hal tersebut mendapat jinayah seperti dalam hadits nabi Muhammad SAW "Telah menceritakan kepada kami 'Abdullah bin Yusuf. Telah mengabarkan kepada kami Malik dan telah menceritakan kepada kami Isma'il telah menceritakan kepada kami Malik dari Ibnu Syihab dari Abu Salamah bin Abdurrahman dari Abu Hurairah radliallahu 'anhu, ada dua wanita Hudzail, salah satunya memukul yang lain sehingga janin yang dikandung keguguran, dan Rasulullah Shallallahu'alaihiwasallam memutuskan untuk membayar ghurrah, budak laki-laki atau hamba sahaya perempuan., 25

Dalam hal kehamilan di luar nikah, terkadang aborsi menjadi solusi yang diartikan dalam arti sempit saja. Dengan demikian berpendapat bahwa setelah melakukan aborsi, semua akan selesai dan menjadi solusi permasalahan. Kenyataan yang ada adalah aborsi menimbulkan kemudharatan lain yang menimpa pelaku.

Dalam sebuah kaidah fiqih, terdapat beberapa kaidah yang memungkinkan dapat diterapkan dalam hasus hamil diluar nikah. آلضَّرَرُ لَا يُزَالُ بِنِْلِهِ

"kemudharatan tidak dihilangkan dengan memunculkan kemudharatan yang semisal apalagi kemudharatan yang lebih parah".

Sesuai dengan kaidah fiqih tersebut, aborsi pada hamil di luar nikah (baik itu perkosaan atau perzinahan) tidak diperbolehkan karena dapat memunculkan kemadharatan yang lebih besar lagi. Penentuan hukum aborsi akibat perzinahan dan perkosaan mempertimbangkan dua hal, yaitu pemeliharaan jiwa perempuan dan janin dalam kandungannya.

${ }^{24}$ Rasyidin Imran, Abortus Dalam Perspektif Hukum Islam Dan Hukum Positif, Jurnal Ilmiah ALMunir, Vol. IV, No. 8, Oktober 2013

${ }^{25}$ Sabarudin Ahmad, Hukum Aborsi Akibat Perkosaan (Analisis Hukum Islam Terhadap Peraturan Pemerintah Nomor 61 Tahun 2014 Tentang Kesehatan Reproduksi ), Jurnal eL-Mashlahah, Vol.8, No.2, 2018

26 https://firanda.com/2464-al-qawaid-al-fiqhiyyah-al-kubra-kemudharatan-dihilangkan-sebisamungkin-kaidah-4.html, diakses pada 10 Desember 2020 pad a jam 14.00 
Dilema yang menimpa aborsi antara memilih ibu atau anak yang dipertahankan tertuang dalam kaedah “ jika terjadi permasalahan tentang dua hal yang merugikan, maka yang harus dipertahankan adalah hal yang mengandung kerugian yang paling berat dan mengorbankan kerugian paling ringan". ${ }^{27}$ Dalam kondisi sedan mengandung, kematian ibu memiliki nilai berat dan janin memiliki nilai ringan. Oleh karenanya, apabila berbicara tentang siapa yang harus dikorbankan yaitu adalah janin, karena janin berasal dari rahim ibu.

Dengan demikian, dibolehkan untuk mengaborsi kandungan apabila telah mencapai taraf dapat mengancam kebinasaan agama, jiwa, akal, keturunan dan harta (ad daruri al khamsah) yang dapat diartikan sebagai keadaan darurat. Dapat dikatakan sebagai segala keadaan yang dapat mengakibatkan atau mengantarkan kepada rusaknya salah satu dari lima hal tersebut dapat dilakukan atau dihalalkan meskipun bertentangan dengan pelarangan dan norma yang berlaku. Pertimbangan tersebut merupakan dasar dari pengambilan hukum dan tidak terpisahkan dengan tujuan menjaga kemaslahatan wanita yang mengandung (ibu). Ibu memiliki tanggungan sosial kepada suami, orang tua maupun tatanan masyarakat yang berada disekitarnya. Sedangkan janin belum ada tanggung jawwab sama sekali.

Para ahli fiqih kontemporer mengharamkan aborsi yang dilakukan tanpa adanya udzur syar'I setelah janin berumur 120 hari atau 4 bulan. Pendapat tersebut didukung oleh Wahbah Az Zuhaili yang mana apabila melakukan aborsi pada umur lebih dari 120 hari maka harus membayar diyat karena hal tersebut memiliki potensi menghilangkan jiwa dan pembunuhan. ${ }^{28}$ Aborsi yang dilakukan sebelum ruh ditiupkan, memiliki kontroversi perbedaan pendapat diantara kalangan ahli fiqih, adapun setelah ditiupkan ruh, hal itu diharamkan karena itu ditandakannya janin sebagai manusia yang memiliki kehormatan dan kemuliaan serta mendapat hak yang ada.

Pengharaman aborsi tidak lain bertujuan untuk menghindari praktik aborsi ketika posisi wanita hamil diluar pernikahan yang mana hal tersebut diharamkan. Hal itu pula agar dapat menjaga kehormatan wanita yang mana efek besar apabila abirsi

\footnotetext{
${ }^{27}$ Moh. Saifullah, Aborsi dan Resikonya Bagi Perempuan (Dalam Pandangan Hukum Islam), Jurnal Sosial Humaniora, Vol. 4, No. 1, Juni 2011

${ }^{28}$ Ririn Fauziyah, Aborsi Dalam Kontroversi Para Fuqaha, Jurnal Hukum Islam Nusantara. Vol. 3, No. 1, Januari - Juni 2020
} 
tidak diharamkan adalah melegalisasi praktik perzinaan di luar nikah dan tidak menjaga kehormatan wanita dan keluargannya. Aborsi terhadap anak hasil perzinaan adalah haram mutlak, ${ }^{29}$ kecuali apabila terdapat keadaan darurat seperti laki-laki yang menzinainya mengancam membunuh dan itu termasuk keadaan darurat yang membolehkan dan menghalalkan aborsi untuk melindungi jiwanya.

\section{Aborsi Menurut Hukum di Indonesia}

Maraknya perzinaan (seks bebas) diluar pernikahan menyebabkan banyaknya kasus aborsi illegal yang dapat membahayakan sang ibu. Hal demikian dikarenakan kehamilan yang tidak diinginkan karena dengan kehamilan, seorang perempuan dapat menyebabkan putus sekolah, gangguan pada kehamilan karena usia yang terlalu muda, ketidaksiapan mental remaja perempuan menghadapi perannya di masa yang akan datang, dan juga berdampak pada perkembangan anak yang dikandungnya. ${ }^{30}$ Aborsi atau pengguguran kandungan merupakan fenomena yang tidak dapat dipisahkan dengan nilai agama, moralitas, sosial, budaya, bahkan nilai politis.

Pengaturan aborsi di Indonesia dalam KUHPidana pasal 299, 346, 347, 348, dan 349, Pasal-pasal tersebut secara transparan dan tegas mengatur tentang larangan aborsi dengan dalih apapun termasuk didalamnya karena seks bebas, maupun tidak serta tenaga medis yang membantu dapat dikenakan sanksi pidana berat, bukan hanya tenaga medis saja akan tetapi meliputi semua pihak yang terlibat didalamnya. ${ }^{31}$

Selain KUHP, menurut Undang-Undang Kesehatan tentang aborsi Pasal 1 yang menyatakan bahwa " dalam keadaan darurat sebagai upaya menyelamatkan jiwa ibu hamil dana tau janinnya, dapat dilakukan tindakan medis tertentu." Pasal ini memanifestasikan legalitas aborsi dengan alasan medis.

Menurut Fatwa Majelis Ulama Indonesia Nomor 4 Tahun 2005 Tentang Aborsi, ${ }^{32}$ dibolehkan melakukan aborsi dengan dua sebab, pertama, darurat (suatu keadaan di mana seseorang apabila tidak melakukan sesuatu yang diharamkan maka ia akan mati atau hampir mati.). Kedua, hajat (suatu keadaan di mana seseorang apabila tidak melakukan sesuatu yang diharamkan maka ia akan mengalami kesulitan berat).

\footnotetext{
${ }^{29}$ Nining, Hukum Aborsi Dalam Perspektif Islam, Jurnal Hukum Replik, Vol. 6, No. 2, September 2018 Juni 2018

${ }^{30}$ Dwiana Ocviyanti \& Maya Dorothea, Aborsi di Indonesia, J Indon Med Assoc, Vol. 68, No. 6,

31 Anik Listiyana, Aborsi Dalam Tinjauan Etika Kesehatan, Perspektif Islam, Dan Hukum Di Indonesia, Egalita: Jurnal Kesetaraan dan Keadilan Gender, Vol, VII, No. 1, Januari 2012, hlm. 61-82

${ }^{32}$ Fatwa Majelis Ulama Indonesia Nomor 4 Tahun 2005
} 
Dengan adanya putusan MUI, sebagai jalan penengah antara perbedaan yang ada dalam pasal KUHP dan UU Kesehatan tentang aborsi. Hal demikian keputusan MUI membolehkan untuk aborsi sesuai dengan anjuran dan melindungi hak seorang ibu apabila harus memilih diantara keduannya.

Pembahasan tentang aborsi merupakan pembahasan kontemporer yang mana kebanyakan terjadi pada kasus MBA (married by accident) yang akan menimbulkan aib bagi keluargannya. Dalam hal ini ada beberapa cara untuk melakukan pencegahan terhadap tindakan aborsi. Pertama, melalui upaya hukum, Indonesia sebagai negara hukum telah mengatur aborsi dalam KUHP, UU Kesehatan, dan fatwa MUI. Hal demikian menjadi jalan untuk menyadarkan masyarakat Indonesia untuk tidak melakukan tindakan aborsi. Kedua, sebagai negara yang beragama, pendekatan keagamaan untuk pencegahan tindakan aborsi memiliki potensi yang sangat besar, karena dengan pendekatan keagamaan akan memahamkan umat tentang kekejian yang akan dilakukannya sehingga tidak memililki balasan dunia melainkan balasan di akhirat.

\section{KESIMPULAN}

Dalam paparan materi di atas, dapat disimpulka bahwa kejadian kasus hamil di luar nikah, banyak terjadi pada kalangan muda saat ini. Dengan perkembangan teknologi yang semakin maju, dimanfaatkan dengan tidak semestinya. Hukum menikahi perempuan hamil menurut hukum islam boleh dengan ketentuan anak dalam kandungannya tidak mendapat hak waris dan tidak ada hubungan nasab. Dalam KHI ayat 53 dijelskan bahwa yang menikahi wanita hamil adalah yang membuatnya hamil. Dengan tujuan untuk menjaga kehormatan keluarganya. Solusi tersebut terbilang baik karena banyak perempuan mengaborsi kandungannya dikarenakan tidak ingin atau tidak mengakui kehamilannya. Solusi yang di jalankan tersebut akan semakin menjerumuskan kedalam jurang kejahatan dan tidak pernah usai.

Aborsi atau abortus adalah pengguguran kehamilan pada usia janin 22 minggu dalam istilah kedokteran. Dalam islam, ulama memiliki perbedaan pendapat tengtang bolehnya melakukan aborsi. Hukum asli aborsi adalah haram, akan tetapi dibolehkan ketika menghadapi keadaan darurat yang mengancam nyawa dari ibu. Dengan demikian tindakan aborsi secara sengaja (abortus provocatus criminal) adalah haram 
dan harus membayar diyat karena telah membunuh janin yang sebagian ulama mengatakan bahwa segumpal darah juga termasuk membunuh, akan tetapi sebagian besar membatasi janin yang dikatakan sebagai manusia dan mendapat haknya adalah janin yang berusia 4 bulan keatas karena telah ditiupkan ruh.

Di Indonesia, kegiatan aborsi menuai pro dan kontra yang terdapat pada KUHP dan UU kesehatan. Dimana keduanya memiliki isi yang berbeda. Hadir sebagai penengah,fatwa MUI menjelaskan bahwa aborsi boleh dilakukan apabila menduduki posisi darurat dan hajat. Pencegahan aborsi pertama memahamkan masyarakat tentang adanya hukum yang berlaku dan kedua melalui pendekatan keagamaan yang mana merupakan ciri khas masyarakat Indonesia. 


\section{DAFTAR PUSTAKA}

Ahmad, S. (2018). Hukum Aborsi Akibat Perkosaan (Analisis Hukum Islam Terhadap Peraturan Pemerintah Nomor 61 Tahun 2014 Tentang Kesehatan Reproduksi ). Jurnal eL-Mashlahah.

Arifin, G. (2020). Menikah Untuk Bahagia; Fiqih Tentang Pernikahan dan Kamasutra Islami. Jakarta: PT. Elex Media Komputindo.

Asep Saepudin Jahar, E. N. (2013). Hukum Keluarga, Pidana, Dan Bisnis: Kajian Perundang-undangan Indonesia, Fikih, Dan Hukum Internasional. Jakarta: Kencana.

Asmarawati, T. (2013). Hukum dan Abortus. Yogyakarta: DEEPUBLISH.

Astutik. (2020). Aborsi Akibat Perkosaan Dalam Perspektif Hukum Kesehatan. Sidoarjo: Zifatama Jawara.

Dewani, R. (2011). Aborsi Dalam Perspektif Hukum Positif Dan Hukum Islam(Suatu Kajian Komparatif). Jurnal Al Al 'Adalah.

Dorothea, D. O. (2018). Aborsi di Indonesia. J Indon Med Assoc.

Fauziyah, R. (2013). Aborsi Dalam Kontroversi Para Fuqaha. Jurnal Hukum Islam Nusantara.

Fatwa Majelis Ulama Indonesia Nomor 4 Tahun 2005

Imran, R. (2013). Abortus Dalam Perspektif Hukum Islam Dan Hukum Positif. Jurnal Ilmiah AL-Munir.

Istibsjaroh. (2012). Aborsi dan Hak-Hak Reproduksi Dalam Islam. Yogyakarta: LKiS Yogyakarta.

Khatib, Y. A. (2005). Fikih Wanita Hamil, penerjemah; Mujahidin Muhayan. Jakarta: Qishti Press. 
Kudrat Abdillah, M. (2010). Sejarah Sosial Status Dan Hak Anak Di Luar Nikah. Pamekasan: Duta Media Publishing.

Listiyana, A. (2012). Aborsi Dalam Tinjauan Etika Kesehatan, Perspektif Islam, Dan Hukum Di Indonesia. Egalita: Jurnal Kesetaraan dan Keadilan Gender,

Millah, S. (2017). Pernikahan Wanita Yang Hamil Di Luar Nikah Dan Akibat Hukumnya : Telaah Atas Dualisme Fikih Dan Kompilasi Hukum Islam. Misykat.

Mohtarom, A. (2018). Kedudukan Anak Hasil Hubungan Zina Menurut Hukum Islam Dan Hukum Positif. Jurnal al-Murabbi.

Montol, M. G. (2017). Tinjauan Yuridis Anak Hasil Zina Dilihat Dari Ketentuan Hukum Islam. Jurnal Lex Crimen.

Mughniyah, M. J. (2004). Fiqih Lima Madzhab, Penerjemah; Masykur A.B, dkk. Jakarta: PT.Lentera Basritama.

Mulyana, T. K. (2015). Tanggung Jawab Dokter Dalam Melakukan Aborsi Tanpa Seijin Ibu Yang Mengandung Ata u Keluarga Dalam Perspektif Hukum Positif Di Indonesia. Jurnal Mimbar Justitia.

Nining. (2018). Hukum Aborsi Dalam Perspektif Islam. Jurnal Hukum Replik.

Pongoliu, H. (2013). Kedudukan Anak Lahir Di Luar Nikah Dalam Perspektif Hukum Islam Dan Hukum Positif. Jurnal Al-Mizan .

Sabiq, S. (2015). Fiqih Sunnah, Penerjemah Ahmad Dzulfikar dan Muhamad Khoiyrurrijal. Depok: Keira Publishing.

Salamah Eka Susanti. (2018). Perubahan Sosial, Ijtihad dan Dinamika Hukum Islam. AsySyari'ah: Jurnal Hukum Islam , 4 (1).

Saifullah, M. (n.d.). Aborsi dan Resikonya Bagi Perempuan (Dalam Pandangan Hukum Islam). Jurnal Sosial Humaniora.

Sudarto. (2020). Masail Fiqhiyah Al Haditsah. Yogyakarta: DEEPUBLISH.

Wijayati, M. (2015). Aborsi Akibat Kehamilan Yang Tak Diinginkan (KTD): Kontestasi Antara Pro-Live Dan Pro-Choice. Jurnal Studi Keislaman. 
Yustisia, S. P. (2006). Kompilasi Hukum Islam. Yogyakarta: Pustaka Widyatama.

Zuhaili, W. A. (2016). Fiqih Islam Wa Adillatuhu, jiid 9, penerjemah; Abdul Hayyi Al Kattani, dkk. Depok: Gema Insani.

https://tafsirweb.com/4636-quran-surat-al-isra-ayat-32.html, diakses pada tanggal 6 Desember 2020 pada jam 18.16 WIB

https://firanda.com/2464-al-qawaid-al-fiqhiyyah-al-kubra-kemudharatan-dihilangkansebisa-mungkin-kaidah-4.html, https://tafsirq.com/24-an-nur/ayat-3 